\title{
Teaching English Language Skills for School Teachers: CTE Programme of IGNOU
}

\author{
Asha Khare \\ (Indira Gandhi National Open University, India) \\ doi:10.7575/aiac.alls.v.2n.1p.1
}

\begin{abstract}
India is a multilingual country. English is the second most important language in the country after the national language Hindi since it is taught as a compulsory subject in all the Indian schools. In the educational system of a multilingual country, it becomes imperative to improve the English Language teaching skills of the school teachers who come from various linguistic backgrounds. The school teacher plays a vital role in the development of linguistic skills of the students. What children learn can affect their later success or failure in school, work, and their personal lives. As such, the school teachers need to improve their own English language skills if they are teaching without any previous English language training. This paper throws light on the communicative approach of English language teaching. It introduces the Certificate in Teaching of English (CTE) programme of the Indira Gandhi National Open University (IGNOU) and outlines the syllabus and the methods used by the university to impart English Language Teaching skills to the elementary/secondary school teachers through this programme with the objective to enhance the teachers' understanding of the learners and their learning process.
\end{abstract}

\section{English teaching and school teachers}

The English teachers in schools need professional training in language skills because they come from various linguistic backgrounds due to the fact that the medium of instruction in Indian schools is either English or the regional language. As such, it is imperative to focus on the needs of learners in a particular community. It needs to be a collaborative activity as well as an individual activity. The particular needs of individuals can be met in this manner. The more highly skilled, motivated and effective are English teachers, the more effective learning outcomes will be for students in English classrooms. 
As per Schon (1987), quality teaching is directly related to the development of a strong and skilled teacher to respond to community and educational concerns, learning outcomes for learners and take a more active role in curriculum planning, including building on and refining existing practices and constantly develop excellent teaching practices.

To maintain and improve the quality of classroom English teaching, the institution should provide initial teacher education and courses appropriate to the needs and requirements of English teachers in close consultation with schools; provide teacher education and courses in language appropriate to the needs and requirements of school teachers; liaise with employing authorities in supporting new curriculum initiatives, designing new courses and supporting professional development initiatives and maintaining an informed, relevant awareness of current practices in schools since teachers' knowledge leads to more effective teaching and learning in classrooms.

Teaching English language skills to English school teachers empowers teachers and meets the identified needs of teachers and schools. It needs to be challenging, informative, innovative and well planned. It is supposed to build skills, involve active participation and team work and be professionally fulfilling and enjoyable.

\section{Programme delivery in IGNOU}

The University has an extensive network of Regional Centres, Learner Support Centres, including Work Centres, Programme Study Centres and Partner Institutions in India (under the convergence scheme), and other countries, through which it reaches out to its learners. At these centres, learners are provided with support services in respect of subject-specific academic counseling, listening/viewing of Audio/Video programmes, library facilities, teleconferencing, video conferencing, computer access, laboratory work and other practical work. For online programmes, the University has established Tele-learning centres at its Regional Centres. Depending on the requirement, the University collaborates with private entrepreneurs to provide work experience and tele-learning facilities to its learners.

Interactive Radio Counseling is broadcast from the studio in the University as well as from 26 FM radio stations across the country. EduSAT channel provides interactive lectures and counseling to learners through SITs, as well as a few DTH platforms. 


\section{English language teaching and teacher training}

English language teaching needs to assure an acquisition of linguistic features, interlanguage patterns (the emerging linguistic system of the language learner), the impact of social and cultural identity on language learning, and the need for intensity of exposure and opportunities to use the language. With the knowledge of these concepts, teachers can structure language learning appropriately for their learners, help them set realistic goals for achievement of levels of proficiency over time, and understand why some students progress faster than others and why some materials and methods work better with particular groups of students than with others (Adger, Snow, \& Christian, 2002).

Individual teaching styles are influenced by one's own experience as a language learner (Borg, 2006; Freeman \& Freeman, 1994). Opportunities should be provided for English teachers to reflect on their own language learning experiences as they implement the same strategies with their learners in their classes (Richards \& Farrell, 2005; Smith, Harris, \& Reder, 2005).

\section{Acquisition of components of language}

Non-native language speakers (Hindi/Regional language) learn components of English language (vocabulary, grammar, accent) differently (Burt, Peyton, \& Adams, 2003; Doughty \& Williams, 1998; Eskey, 2005; Flahive \& Bailey, 1993; Folse, 2004; Nation, 2000, 2005). The non-native language speakers may not know enough words in English to be able to use it correctly. Teachers of adult English language learners need to know what strategies for teaching reading, writing, listening, and speaking are most effective with adults learning English.

\section{Certificate in Teaching of English (CTE) programme}

The CTE programme, offered by the Indira Gandhi National Open University, is based on the communicative approach to English language teaching. It is designed to enhance the teachers' understanding of the learners. It ensures that the English language teaching/learning process is near native and the teacher is able to explain the nature and structure of the English language correctly to the learners. It helps the non-native English teachers to innovate strategies for teaching the language skills of listening, speaking, reading and writing. It teaches the English teachers new and more effective methodologies of classroom management, material selection and evaluation. It provides an update on the current theories 
in the area of English teaching. It deals with the practical problems of the teachers in the classrooms. It attempts to understand the learner factors, i.e., aptitude, attitude, motivation, age, sex and previous experience of learning. The aim of the programme is to make the teacher aware that language is a dynamic entity and subject to variation and change. English is spoken differently in different parts of the world as well as in different regions of India. Hence, the over-emphasis on purist 'norms', and 'standards' should be avoided by the teacher.

There are four courses in this programme. Three courses are compulsory and one is optional as per the following details:

\section{Compulsory Courses}

CTE-1 The Language Learner

CTE-2 The Structure of English

CTE-3 Teaching Strategies

$\underline{\text { Optional Courses }}$

CTE-4 Teaching English-Elementary School

CTE-5 Teaching English-Secondary School

\section{Methods of Teaching}

The course CTE-1 focuses on the learners and gives their general description in terms of their capabilities and learning resources (personal and social). It enables the teacher to:

- Provide more efficient learning strategies

- Assist learners in identifying their own preferred ways of learning

- Encourage learners to set their own objectives

- Develop learners' skills in self-evaluation

The course CTE-2 provides a good knowledge of the structure of English and its usage in order to improve classroom strategies of teachers for teaching the Indian variety of English.

The course CTE-3 deals with the teaching strategies for creating special contexts to provide learning opportunities and learning experiences and to support and promote learning of English language by learners in India. 
The course CTE-4 gives insight into the development of personality, cognition and language development of the young learners of Elementary level. The teachers at this level have serious responsibility because these learners are at a formative stage in their life and all the dimensions of their personhood (emotional, social, physical and intellectual) are in the making.

The course CTE-5 is meant for the middle and secondary school teachers. It is of practical nature since it gives examples of classroom experiences to the teachers. New strategies as well as new materials in teaching the four skills of reading, writing, speaking and listening are suggested in it. Moreover, it deals with the new techniques in evaluating these skills too.

\section{Conclusion}

In the educational system of a multilingual country, it becomes imperative to improve the English Language teaching skills of the school teachers who come from various linguistic backgrounds. The school teacher plays a vital role in the development of linguistic skills of the students. What children learn can affect their later success or failure in school, work, and their personal lives.

The CTE programme of IGNOU is especially designed for those English teachers of elementary/secondary school who teach in large classes with few resources, follow a set syllabus and text book, have little time for lesson planning and lack teaching aids/equipment. The programme helps them to gain insights about the language learners, not only as a cognitive entity, but as a social being functioning in a multilingual environment. It enables them to understand the nature of language as a dynamic entity, subject to variation and change. It enhances their proficiency in English, not only in terms of structure of English (sounds, words, grammar) but also at the level of discourse. It helps them to critically reflect over their classroom experiences and innovate in teaching strategies so that they can teach the four skills more effectively. It upgrades them in the prevalent new theories in terms of the learners, learning process, classroom management, material selection and creation, evaluation and methodology of teaching. 


\section{References}

Adger, C., Snow, C., \& Christian, D. (Eds.). (2002). What teachers need to know about language. Washington, DC: Center for Applied Linguistics.

Borg, S. (2006). Teacher cognition and language education. New York: Continuum.

Burt, M., Peyton, J. K., \& Adams, R. (2003). Reading and adult English language learners: A review of the research. Washington, DC: Center for Applied Linguistics.

Doughty, C., \& Williams, J. (1998). Pedagogical choices in focus on form. In Doughty \& J. Williams (Eds.), Focus on form in classroom second language acquisition (pp.114-138). New York: Cambridge University Press.

Eskey, D. (2005). Reading in a second language. In E. Hinkel (Ed.), Handbook of research in second language teaching and learning (pp.563-580). Mahwah, NJ: Erlbaum.

Farrell, T. S. C. (2004). Reflective practice in action. Thousand Oaks, CA: Corwin Press.

Flahive, D. E., \& Bailey, N. H. (1993). Exploring reading/writing relationships in adult second language learners. In J. Carson and I. Leki (Eds.), Reading in the composition classroom (pp. 128-140). Boston: Heinle \& Heinle.

Folse, K. S. (2004). Vocabulary myths: Applying second language research to classroom teaching. Ann Arbor: University of Michigan.

Freeman, D. E., \& Freeman, Y. S. (1994). Between worlds: Access to second language acquisition. Portsmouth, NH: Heinemann.

Nation, I. M. P. (2000). Learning vocabulary in lexical sets: Dangers and guidelines. TESOL Journal, 9(2), 6-10.

Nation, I. M. P. (2005). Teaching and learning vocabulary. In E. Hinkel (Ed.), Handbook of research in second language teaching and learning (pp. 581-595). Mahwah, NJ: Erlbaum.

Richards, J., \& Farrell, T. S. C. (2005). Professional development for language teachers. New York: Cambridge University Press.

Schon, D. A. (1987). Educating the reflective practitioner . San Francicsco: Jossey

Smith, C., Harris, K., \& Reder, S. (2005). Applying research findings to instruction for adult English language learners. Washington, DC: Center for Adult English Language Acquisition. 